\title{
ZASADA NULLUM CRIMEN SINE LEGE CERTA I JEJ OGRANICZENIA NA TLE JĘZYKA ETNICZNEGO
}

\section{WPROWADZENIE}

Odpowiedzialność karna może być uzasadniona tylko zachowaniem, które uprzednio zostało precyzyjnie i jednoznacznie określone jako zakazane, i na domiar tego wyłącznie w drodze aktu prawnego o randze ustawy. Prezentowana myśl stanowi owoc oświeceniowego humanizmu, w duchu którego człowiek stał się głównym obiektem zainteresowań ówczesnych wolnomyślicieli. Wśród „wyzwolonych” filozofów i prawników tej epoki pojawiły się hasła, iż człowiek, jako istota o przyrodzonej i niezbywalnej godności, powinien mieć zagwarantowaną ochronę podstawowych wolności i praw. Nowożytna cywilizacja stała się zatem świadkiem wielu przemian społeczno-politycznych, które odbywały się w trakcie takich wydarzeń, jak rewolucja francuska, Konstytucja 3 maja w Polsce, Deklaracja niepodległości i Konstytucja USA itd. Zmiany te nie ominęły dziedziny prawa, w ramach której dochodziło do represji i karania przez państwo za czyny społecznie niechciane i nieakceptowane. Chociażby w art. VIII francuskiej Deklaracji praw człowieka i obywatela z 26 sierpnia 1789 r. stwierdzono, że „ustawa może wprowadzać tylko takie kary, które sa oczywiście i ściśle potrzebne i nikt nie może być karany inaczej, jak tylko na podstawie ustawy wydanej i ogłoszonej przed popełnieniem przestępstwa oraz gdy ta ustawa została zastosowana w sposób zgodny z prawem"1.

La Fayette w założeniach projektu Deklaracji dążył do ujęcia człowieka jako jednostki wolnej od nadużyć ze strony ówczesnej, feudalnej władzy. W tym zakresie drobnym na tle całych zmian ustrojowych, lecz istotnym dla nowożytnego pojmowania prawa karania było twierdzenie, że człowiek „wolny” powinien mieć możliwość obiektywnego rozpoznawania tego, co jest mu zabronione pod groźbą kary. Jakub Kociubiński przypomina, że Paul von Feuerbach określał tę zasadę mianem „granicy samowoli państwa”2. Stąd też, zro-

\footnotetext{
${ }^{1}$ Art. VIII w oryginale: „La Loi ne doit établir que des peines strictement et évidemment nécessaires, et nul ne peut être puni qu'en vertu d'une Loi établie et promulguée antérieurement au délit, et légalement appliquée". Źródło: <fr.wikisource.org> [dostęp: 27.03.2016].

${ }^{2}$ J. Kociubiński, Zasada nullum crimen, nulla poena sine lege $i$ jej ograniczenia $w$ orzecznictwie Europejskiego Trybunału Praw Człowieka, w: Nowa Kodyfikacja Prawa Karnego, t. 38, Wrocław 2012, s. 269.
} 
dzona z humanistycznej myśli oświecenia, idea nullum crimen sine lege stała się podwalina późniejszych, demokratycznych regulacji prawa karnego.

Wobec powyższego niniejszy artykuł stanowi próbę rozstrzygnięcia kwestii, czy możliwe jest urzeczywistnianie w pełni głównych założeń, jakie legły $\mathrm{u}$ podstaw formułowania $\mathrm{w}$ okresie oświecenia zasady nullum crimen sine lege, w tym nullum crimen sine lege certa. Problem ten analizowany jest w kontekście zjawiska języka etnicznego, w jakim formułowane sa przepisy określajace karalne typy zachowań, albowiem język ten, jako podstawowe narzędzie ustawodawcy, jest niedoskonały, charakteryzuje się bowiem brakiem precyzji, niedookreślonością lub wieloznacznością spotykanych w nim słów, a niekiedy całych złożonych fraz. Jednocześnie na gruncie tych rozważań przyjmowana jest teza, że przepisy karne, z uwagi na to, że wyrażaja normy zaadresowane do ogółu społeczeństwa, winny być na tyle zarozumiałe dla przeciętnych obywateli, aby nie dysponując odpowiednim przygotowaniem prawniczym i umiejętnością przeprowadzania skomplikowanych procederu wykładni normy karnej z przepisu karnego, mogli ustalić, co można, a czego nie można czynić.

\section{NULLUM CRIMEN SINE LEGE PO II WOJNIE ŚWIATOWEJ}

Renesansem dla nullum crimen sine lege okazała się druga połowa XX w. Zasada ta była już wprawdzie w kodeksach karnych przed I i II wojna światowa, niemniej to dopiero po II wojnie państwa alianckie oraz państwa dawnej Osi, nauczone przykładem instrumentalnego wykorzystywania prawa karnego w reżimach totalitarnych, zadeklarowały konieczność powrotu do państwa prawa w sferze prawa karania. Jednocześnie podkreślono potrzebę takiego kształtowania podstaw odpowiedzialności karnej, by obywatele mieli zagwarantowaną ochronę przed arbitralnymi działaniami organów ścigania i wymiaru sprawiedliwości.

W rezultacie 26 czerwca 1945 r. podczas Konferencji w San Francisco podpisano Kartę Narodów Zjednoczonych, w której zwrócono uwagę na potrzebę zwiększenia gwarancji przestrzegania praw człowieka. W art. 1 ust. 3 Karty podkreślono, że należy doprowadzić do współdziałania międzynarodowego w zakresie popierania i zachęcania do poszanowania praw człowieka i podstawowych wolności dla wszystkich, bez względu na rasę, płeć, język lub wyznanie. Natomiast zasadę nullum crimen sine lege w dosłownym jej brzmieniu ujęto w ramy Powszechnej deklaracji praw człowieka, sporządzonej w Paryżu w trakcie Trzeciej Sesji Ogólnego Zgromadzenia ONZ, 10 grudnia 1948 r. Zgodnie z art. 11 ust. 2 Deklaracji nikt nie może być skazany za przestępstwo z powodu działania lub zaniechania niestanowiącego w chwili jego dokonania przestępstwa według prawa krajowego lub międzynarodowego. Na gruncie tej Deklaracji, a jednocześnie w głębokiej wierze w podstawowe wolności człowieka powtórzono tę zasadę w art. 7 Konwencji o ochronie praw człowieka i podstawowych wolności, podpisanej w Rzymie w 1950 r. (ratyfikowanej przez 
Polskę w 1993 r.). Na podstawie art. 7 nikt nie może być uznany za winnego popełnienia czynu polegającego na działaniu lub zaniechaniu działania, który według prawa wewnętrznego lub międzynarodowego nie stanowił czynu zagrożonego kara w czasie jego popełnienia.

Innym doniosłym aktem prawa międzynarodowego, w którym również została zawarta zasada nullum crimen sine lege, jest Międzynarodowy pakt praw obywatelskich i politycznych z Nowego Jorku z 19 grudnia 1966 r. (ratyfikowany przez Polskę w 1977 r.). W myśl art. 15 ust. 1 Paktu nikt nie może być skazany za czyn lub zaniechanie, które w myśl prawa wewnętrznego lub międzynarodowego nie stanowiły przestępstwa w chwili ich popełnienia.

Zasada nullum crimen sine lege stanowi współcześnie element wspólnotowego acquis communautaire. Ujęto ja w Karcie praw podstawowych Unii Europejskiej, w art. 49 ust. 1; zgodnie z nim nikt nie może zostać skazany za popełnienie czynu polegającego na działaniu lub zaniechaniu, który według prawa krajowego lub prawa międzynarodowego nie stanowił czynu zabronionego pod groźbą kary w czasie jego popełnienia.

\section{NULLUM CRIMEN SINE LEGE W POLSCE}

Po odzyskaniu przez Polskę niepodległości oświeceniowa myśl nullum crimen sine lege znalazła wyraz w Konstytucji marcowej z $1921 \mathrm{r}$. Zgodnie z art. 98 ściganie obywatela i wymierzenie kary było dopuszczalne tylko na zasadzie obowiązującej ustawy3. W Konstytucji kwietniowej z $1935 \mathrm{r}$. zasadę tę powtórzono w ten sposób, że zgodnie z art. 68 ust. 4 nikt nie mógł być karany za czyn niezabroniony przez prawo przed jego popełnieniem ${ }^{4}$.

Po II wojnie światowej nullum crimen sine lege nie znalazła bezpośredniego wyrazu w Konstytucji z 1952 r. Było to uzasadnione ówczesną sytuacją społeczno-polityczna, w okresie stalinowskim bowiem prawo karne było kształtowane tak, aby eliminować ze społeczeństwa osoby poczytywane za wrogów pracującej klasy robotniczo-chłopskiej. Nie mieliśmy do czynienia z prawem karnym czynu, tj. karzacym za zachowania. Wykorzystywano je jako instrument władzy, eliminujący ze społeczeństwa jednostki niepożądane (szkodliwe). Przykładem takiej praktyki było orzeczenie SN z 12 września 1951 r., który zważył, iż badając przesłanki odpowiedzialności karnej, należy brać pod uwagę całokształt osobowości sprawcy, a w szczególności jego pochodzenie społeczne i stosunek do rzeczywistości (w konkretnym przypadku mowa była o stosunku do rzeczywistości w Polsce Ludowej). Takie rozważania przeprowadzono w odniesieniu do przestępstwa z art. 22 m.k.k. Mianowicie na tle tego czynu, nie każda uwaga krytyczna musiała stanowić fałszywą wiadomość mogącą wyrządzić szkodę interesom Państwa Polskiego. „Uwaga” taka, jeżeli została wypowiedziana przez wroga klasowego, niewątpliwie winna stanowić

${ }^{3}$ Konstytucja RP z 17 marca 1921 r. (Dz. U. 1921, Nr 44, poz. 267).

${ }^{4}$ Konstytucja RP z 23 kwietnia 1935 r. (Dz. U. 1935, Nr 30, poz. 227). 
przestępstwo. Jeżeli jednak ta sama „uwaga” została wypowiedziana przez obywatela pozytywnie ustosunkowanego do Polski Ludowej, to wówczas można było ją uznać za wyraz błędnego przekonania, które można było sprostować bez konsekwencji prawnokarnych ${ }^{5}$.

Nie było jednak tak, że w Polsce Ludowej o nullum crimen sine lege w ogóle zapomniano. Zaczęto przypominać sobie o niej już w okresie po odwilży. Andrzej Zoll podkreśla nawet, że praktyka okresu PRL wypracowała rozumienie tej zasady w ścisłym powiązaniu z zasadą demokratycznego państwa prawa, a zatem była zauważana w literaturze i orzecznictwie jeszcze przed zmianami ustrojowymi w 1989 r. ${ }^{6} \mathrm{Z}$ tym że w odniesieniu do tej zasady wskazywane były dwa poglądy co do jej źródła. Niektórzy przypisywali jej rangę konstytucyjnej zasady, albowiem jako taka była wyprowadzana z innych zasad, wyrażanych w ówczesnej ustawie zasadniczej. Z drugiej strony proponowano, aby zasadę tę traktować jako ustawowa, czyli obowiązującą wyłącznie na gruncie ustawodawstwa ${ }^{7}$.

Wreszcie w Konstytucji RP z 1997 r. ustrojodawca zawarł w art. 42 ust. 1, że odpowiedzialności karnej podlega ten tylko, kto dopuścił się czynu zabronionego pod groźbą kary przez ustawę obowiązującą w czasie jego popełnienia. Powtórzeniem nullum crimen sine lege z art. 42 ust. 1 Konstytucji RP jest art. $1 \S 1$ k.k. z 1997 r., zgodnie z którym odpowiedzialności karnej podlega ten tylko, kto popełnia czyn zabroniony pod groźbą kary przez ustawę obowiązująca w czasie jego popełnienia, a w myśl art. $115 \S 1$ k.k. czynem zabronionym jest zachowanie o znamionach określonych w ustawie karnej.

\section{NULLUM CRIMEN SINE LEGE CERTA}

Zasada nullum crimen sine lege stanowi jeden $\mathrm{z}$ podstawowych standardów demokratycznego państwa prawa ${ }^{8}$. Przypisuje się jej szczególny status, albowiem w ramach prawa karnego stosowane sa najdrastyczniejsze, znane polskiemu systemowi prawnemu formy ingerencji w podstawowe prawa i wolności człowieka9. Normy prawa karnego winny być zatem zawarte w akcie rangi ustawowej i przy tym w taki sposób ujęte, by precyzyjnie i jednoznacznie

5 Wyrok SN z 12 września 1951 r., I K 206/51.

${ }^{6}$ A. Zoll, Zasada określoności czynu zabronionego pod groźba kary w orzecznictwie Trybunału Konstytucyjnego, w: M. Zubik, K. Budziło (red.), Księga XX-lecia orzecznictwa Trybunału Konstytucyjnego, Warszawa 2006, s. 526-527.

${ }_{7}$ M. Sławiński, Konstytucyjne uwarunkowania zasady nullum crimen sine lege - uwagi na marginesie wykładni art. 42 ust. 1 Konstytucji RP, w: I. Sopieło (red.), Nullum crimen sine lege, Warszawa 2013, s. 28.

${ }^{8}$ L. Gardocki, Zasada nullum crimen sine lege certa we wspótczesnym polskim prawie karnym, w: A. Dębiński et al., (red.), Hominum causa omne ius constitutum est. Księga jubileuszowa ku czci profesor Alicji Grześkowiak, Lublin 2006, s. 71; A. Zoll, op. cit., s. 526; P. Kokot, Nullum crimen sine lege jako dyrektywa interpretacji tekstu prawnego, w: I. Sepioło (red.), op. cit., s. 3.

${ }^{9}$ A. Zoll, op. cit., s. 526. 
wyrażać ustawowe znamiona typizowanych czynów zabronionych ${ }^{10}$. Opis typu czynu winien być precyzyjny i ścisły ${ }^{11}$. Innymi słowy, istnieje w tym zakresie nakaz „wyraźnego zdefiniowania przestępstwa” 12 .

$\mathrm{Na}$ gruncie nullum crimen sine lege urzeczywistniana jest funkcja gwarancyjna prawa karnego. Aparat państwowy winien być powstrzymywany od arbitralnych działań, stwarzających nieuzasadnione niebezpieczeństwo dla praw i wolności jednostek ${ }^{13}$. Twierdzenie takie zaprezentował również na tle art. 7 Konwencji o ochronie praw człowieka i podstawowych wolności Europejski Trybunał Praw Człowieka, albowiem w jego przekonaniu zadaniem nullum crimen sine lege jest ochrona jednostek przed arbitralnym ściganiem, uznawaniem winy i karaniem ${ }^{14}$. Tym samym art. 7 Konwencji, wyrażajacy zasadę nullum crimen sine lege, jako ważny element zasady rządów prawa jest przepisem niederogowalnym w rozumieniu art. 15 ust. 2 Konwencji - nawet w sytuacji zagrożenia bezpieczeństwa publicznego ${ }^{15}$.

Nullum crimen sine lege zawiera cztery podstawowe nakazy. Pierwsze dwa odnoszą się do kwestii stanowienia normy karnych, tj. zaadresowany do prawodawcy karnisty nakaz stanowienia norm karnych zawierajacych znamiona czynów zabronionych w drodze aktu prawnego wyłącznie rangi ustawowej (nullum crimen sine lege scripta) ${ }^{16}$ oraz nakaz określoności znamion (nullum crimen sine lege certa $)^{17}$. Dwa pozostałe odnoszą się już do etapu stosowania prawa karnego, albowiem w tym zakresie mieści się postulat wyłączający wsteczne działanie przepisów pogorszających sytuację sprawcy (nullum crimen sine lege praevia) oraz zakaz stosowania niekorzystnej dla sprawcy wykładni rozszerzajacej (nullum crimen sine lege stricta) ${ }^{18}$.

W ramach prezentowanych rozważań szczególnie interesujaca jest zasada nullum crimen sine lege certa. Jako gwarancja przed „swobodna twórczością" ustawodawcy zaliczana jest stricte do dyrektyw wskazujacych, jak w optymalny sposób formułować tekst aktów prawotwórczych, tj. zarysowuje warunki odnoszące się do sposobu określenia typu czynu zabronionego pod groźbą kary ${ }^{19}$. Innymi słowy, chodzi tutaj o to, aby ustawodawca sformułował taki opis cech zewnętrznych typu ludzkiego zachowania, jego skutków oraz okoliczności towarzyszących, który w sposób niebudzący wątpliwości pozwoli każdorazowo na identyfikację w obserwowanej rzeczywistości czynu zabronionego. Normy karne muszą być dostatecznie jednoznaczne po to, by

${ }^{10}$ L. Gardocki, op. cit., s. 71; wyroki TK: z 24 lutego 2003 r., K 28/02, Lex 76811; z 15 września 1999 r., K 11/99, Lex 38257; z 16 stycznia 2006 r., SK 30/05; z 7 stycznia 2004 r., K 14/03.

11 Wyrok TK z 17 lutego 2015 r., K 15/13, Lex 1186188; J. Warylewski, Zasady techniki prawodawczej. Komentarz do rozporzqdzenia, Warszawa 2003, s. 326.

12 J. Kociubiński, op. cit., s. 274.

${ }^{13}$ Ł. Pohl, Prawo karne. Wyktad części ogólnej, Warszawa 2012, s. 32; P. Kokot, op. cit., s. 6.

${ }_{14}$ Wyrok ETPC z 24 lipca 2008 r., Kononov vs. Eotwa, Lex nr 136785.

15 J. Kociubiński, op. cit., s. 272.

16 A. Zoll, op. cit., s. 528 i n.; J. Kociubiński, op. cit., s. 270.

17 J. Kociubiński, op. cit., s. 270.

18 Ibidem.

19 A. Michalska, S. Wronkowska, Zasady tworzenia prawa, Poznań 1983, s. 56. 
bez cienia wątpliwości można było wskazać, kto, kiedy i co ma albo czego nie ma czynić ${ }^{20}$.

Jednoznaczność przepisu ma minimalizować niebezpieczeństwo wyprowadzania wielu rozwiązań interpretacyjnych ${ }^{21}$. Z tym wiąże się konieczność zachowania „kompletności” i „precyzyjności” przepisu ${ }^{22}$. Nullum crimen sine lege certa nakazuje zatem ustawodawcy „takie wskazanie czynu zabronionego (jego znamion), aby zarówno dla adresata normy prawnokarnej, jak i organów stosujacych prawo i dokonujacych „odkodowania” treści regulacji w drodze wykładni normy prawa karnego nie budziło wątpliwości to, czy określone zachowanie in concreto wypełnia te znamiona" ${ }^{23}$. W innym razie proces oceny tego, czy dane zachowanie wyczerpało znamiona czynu zabronionego, będzie polegał „nie na w miarę prostej subsumcji, lecz niemal na »tworzeniu prawa« na podstawie zasad prawnych, zasad przewodnich, mniej lub bardziej abstrakcyjnych wartości prawnych" 24 .

Trzeba mieć jednak na uwadze, że nullum crimen sine lege certa obliguje jeszcze do zachowania równowagi między nadmierną kazuistycznościa przepisu karnego a nadmierną jego kauczukowościa. Dążenie do tak pożądanej jednoznaczności przepisu, jego precyzji i kompletności znamion, nie może odbywać się kosztem tworzenia przepisów wysławiających normy, które nie sa abstrakcyjne i generalne. Tworzenie bowiem przepisów kazuistycznych mija się $\mathrm{z}$ istota regulacji z art. 42 ust. 1 Konstytucji RP. Mowa w tym zakresie o wyznaczeniu dopuszczalności i zakresu stosowania norm prawa karnego o charakterze blankietowym ${ }^{25}$. Istnieje bowiem potrzeba przedstawienia abstrakcyjnego i generalnego opisu typu zachowania, a nie konkretnego zachowania. Z drugiej strony nadmierna kauczukowość przepisu może prowadzić do tego, że adresat normy karnej nie będzie mógł zrekonstruować zasadniczych znamion czynu zabronionego, a to stanowi już naruszenie $n u l$ lum crimen sine lege certa. Podkreśla się bowiem, że „jakiekolwiek wskazanie ogólnikowe, umożliwiające daleko idąca swobodę interpretacji co do zakresu znamion czynu zabronionego, czy pewnego typu kategorii zachowań, nie może być traktowane jako spełniające wymóg określoności na gruncie art. 42 ust. 1 Konstytucji RP”26.

Poza powyższą koniecznością znalezienia „złotego środka”, czyli zapewnienia równowagi między kazuistycznością i kauczukowością przepisu karnego, istnieje jeszcze jedna kwestia, z powodu której także dochodzi do perturbacji

${ }^{20}$ Ł. Pohl, Komentarz do art. 1 K.k., w: R.A. Stefański (red.), Kodeks karny. Komentarz, Warszawa 2011, Legalis.

${ }^{21}$ Ibidem.

${ }^{22}$ A. Zoll, op. cit., s. 527; orzeczenie TK z 26 kwietnia 1995 r., K 11/94, Lex 25538; postanowienia TK: z 25 września 1991 r., S 6/91, Lex 25373; z 13 czerwca 1994 r., S 1/94, Lex 25121; orzeczenie TK z 1 marca 1994 r., U 7/93, Lex 25109; wyroki TK: z 26 listopada 2003 r., SK 22/02, OKA-A 2003, nr 9, poz. 97; z 28 czerwca 2005 r., SK 56/04, OTK-A 2005, nr 6, poz. 67.

${ }^{23} \mathrm{Z}$ uzasadnienia wyroku TK z 17 lutego 2015 r., K 15/13, Lex 1186188.

${ }^{24}$ K. Mamak, Niejasny opis typu czynu a zasada nullum crimen sine lege, w: I. Sepioło (red.), op. cit., s. 67.

${ }^{25}$ Wyrok TK z 17 lutego 2015 r., K 15/13, Lex: 1186188, oraz z 9 czerwca 2010 r., SK 52/08.

${ }^{26} \mathrm{Z}$ uzasadnienia wyroku TK z 17 lutego 2015 r., K 15/13, Lex nr 1186188. 
w procesie dochodzenia do jednoznaczności i precyzji znamion typu czynu, tj. potrzeba zachowania „komunikatywności” i „zwięzłości” opisu znamion ${ }^{27}$. Stąd też „idealna” jednoznaczność i precyzja przepisu karnego wydawać się może po prostu nieosiagalna. Język prawny jest bowiem rezultatem kompromisu między właśnie precyzją a komunikatywnością dla jak największej liczby osób oraz zwięzłością tekstu prawnego ${ }^{28}$.

Wreszcie problemem jest polisemiczność języka etnicznego, w jakim przepis karny jest formułowany. Niedoskonałość tego języka, w tym jego nieprecyzyjnośćc ${ }^{29}$, przyczynia się znacząco do nazbyt kauczukowego ujmowania znamion czynów zabronionych.

Powyższe ograniczenia, tj. a) konieczność wysławiania norm abstrakcyjnych i generalnych (złoty środek między kauczukowościa, a kazuistycznością przepisu), b) potrzeba zachowania zwięzłość i komunikatywności przepisu, c) polisemia bądź homonimia języka etnicznego sprawiaja problemy w kwestii doboru słownictwa i konstrukcji przepisu (tekstu prawnego). Nieumiejętnie dobrane słownictwo oraz nieumiejętnie skonstruowane przepisy będa prowadziły do nieprecyzyjnego, zawiłego bądź też szerokiego opisu typu czynu zabronionego ${ }^{30}$. W literaturze podkreśla się, że w przepisie karnym zawierajaccym nieprecyzyjny opis znamion typu czynu „ustawodawca wychodzi poza planowany pierwotnie zakres penalizacji, pozostawiajac jednocześnie poza możliwościami kwalifikowania z tego przepis zachowań, które stały u podstaw podjęcia decyzji o utworzeniu ustawowego wzorca karalnego zachowania". Przepis zawiły zawiera zaś opis, w ramach którego wysławiany jest „zakres normowania wprawdzie odpowiadający planom ustawodawcy, jednak jego zrozumienie związane jest z koniecznością mozolnego rozszyfrowywania”. Szeroki przepis to przepis zawierajacy „wzorzec karalnego zachowania, który swoim zakresem oddziaływania daleko wykracza poza intencje ustawodawcy i faktyczne potrzeby polityki karnej”" ${ }^{31}$. Dlatego też umiejętność poprawnego formułowania tekstu prawnego jest pożądanym panaceum na nieprawidłowości w zakresie arbitralnego, ,interpretacyjnego tworzenia” prawa przez organy stosujace nieprecyzyjnie wyrażone normy prawne. W przeciwnym razie, jak zaznaczają Sławomira Wronkowska i Maciej Zieliński, nieumiejętnie sformułowane przepisy prawne mogą być pozornym pośrednikiem między władzą prawodawczą a odbiorcami prawa ${ }^{32}$. Podmiot kompetentny do stanowienia prawa winien zarówno tworzyć poprawne przepisy, jak i kształtować poprawny system prawny ${ }^{33}$.

${ }_{27}$ A. Michalska, S. Wronkowska, op. cit., s. 66.

28 Ł. Pohl, Komentarz do art. 1 K.k. ..., passim.

29 A. Michalska, S. Wronkowska, op. cit., s. 67.

${ }^{30}$ K. Mamak, op. cit., s. 61.

31 Ibidem.

32 S. Wronkowska, M. Zieliński, Komentarz do zasad techniki prawodawczej, Warszawa 2004, s. 7.

${ }^{33}$ Ibidem, s. 19-21. 


\section{JĘZYK OGÓLNY, JĘZYK PRAWNY, JĘZYK PRAWNICZY A ZASADY TECHNIKI PRAWODAWCZEJ}

Powyższe pośrednio dowodzi tego, że zasada nullum crimen sine lege certa, w kontekście ZTP, jest nierozerwalnie związana z zagadnieniem języka ogólnego, prawnego, jak również prawniczego. Nie można bowiem uciec od analizy tego zagadnienia przez pryzmat zjawiska języka, w jakim przepis jest formułowany. Dlatego też można stwierdzić, że konkretyzacja treści nullum crimen sine lege certa następuje na poziomie zasad techniki prawodawczej (ZTP), albowiem odnoszą się one stricte do sposobu postępowania przez ustawodawcę z językiem, czym też stanowią konkretne, redakcyjno-techniczne wytyczne określające sposób formułowania przepisu. Wytyczne te są dla ustawodawcy czytelną instrukcją, określająca, jak należy zredagować przepis, aby nie sformułować go w brzmieniu dalekim od wzorca właściwego dla nullum crimen sine lege certa (zresztą nie tylko dla tej zasady, lecz w ujęciu całego systemu prawnego). Zasady techniki prawodawczej są swoistą odpowiedzią na niedoskonałości języka powszechnego.

Językoznawcy - jak podkreśla M. Zieliński - posługują się dla języka prawnego mianem „stylu urzędowego" ${ }^{34}$. W teorii prezentowane sa w odniesieniu do zagadnienia statusu języka prawnego dwa zasadnicze podejścia. W myśl jednego z poglądów język prawny traktuje się jako pozostający w odpowiedniej interakcji względem leksyki języka potocznego ${ }^{35}$. Na gruncie innych, mniej bądź bardziej zbliżonych sobie stanowisk, kładzie się nacisk na odejście od języka potocznego z powodu odmiennej od języka prawnego leksyki. Przykładowo Agnieszka Choduń odrzuca możliwość uznania języka prawnego za odmianę polskiego języka potocznego ${ }^{36}$. Jej zdaniem nieaktualna jest koncepcja Bronisława Wróblewskiego, na gruncie której baza leksykalna języka ustawy wywodzi się z ,języka potocznego". Wróblewski wiązał ten ostatni z językiem używanym w nieoficjalnych sytuacjach przez środowiska wykształcone. $\mathrm{Na}$ przestrzeni ponad pół wieku język potoczny przeszedł jednak przemianę od postaci, którą posługiwali się ludzie wykształceni, do znanej szerszemu gronu społeczeństwa pod nazwa „mowy codziennej”. Język potoczny nie jest już wyłącznie odmianą języka ludzi wykształconych. Stał się używaną w prywatnych, nieoficjalnych sytuacjach mową codzienna ${ }^{37}$. W literaturze wyróżnia się zaś język powszechny, język ogólny, język ogólny formalny, a w tekście prawnym należy właśnie używać słów w ich znaczeniu ogólnym ${ }^{38}$.

Zgodnie z $§ 8$ ust. 1 ZTP przy redakcji teksu aktu prawnego należy posługiwać się tymi słowami lub sensownymi ich zestawieniami, które funk-

${ }^{34}$ M. Zieliński, Wykładnia prawa. Zasady, reguły, wskazówki, Warszawa 2012, s. 195.

${ }^{35}$ J. Wróblewski, w: W. Lang, J. Wróblewski, S. Zawadzki (red.), Teoria państwa i prawa, Warszawa 1979; L. Morawski, Wstęp do prawoznawstwa, Torun 2000.

${ }^{36}$ A. Chodun, Leksyka tekstów aktów prawnych, „Ruch Prawniczy, Ekonomiczny i Socjologiczny" 68,2006 , z. 4, s. 29;

37 Ibidem.

${ }^{38}$ A. Malinowski, Polski tekst prawny. Opracowanie treściowe i redakcyjne, Warszawa 2012, s. 21 . 
cjonują jako poprawne wyrażenia językowe (określenia) o ich podstawowym i powszechnym znaczeniu. „Powszechność znaczenia” danego słowa jest antonimem potoczności, w tym żargonowości wypowiedzi. Innymi słowy, konkretne określenie winno być używane w znaczeniu zrozumiałym dla możliwe najszerszego grona osób, posługujących się danym językiem etnicznym ${ }^{39}$. „Powszechne znaczenie” to znaczenie ogólnoetniczne, współczesne oraz używane przez najszersza grupę społeczeństwa ${ }^{40}$. „Podstawowe znaczenie” danego słowa jest to zaś takie, które ma charakter pierwszoplanowy ${ }^{41}$. Pierwszoplanowe, czyli używane najczęściej. Język ogólny stanowi „odmianę kulturalnego języka narodowego, upowszechnioną przez szkołę, administrację, literaturę, media służąca jako środek porozumiewania się we wszystkich dziedzinach członkom narodu" 42 .

Język prawny może pozostawać względem języka ogólnego w dwóch zasadniczych relacjach: 1) terminologicznej, polegającej na używaniu znaków słownych z języka ogólnego, 2) pojęciowej, polegającej na używania tych znaków słownych o ich ogólnym znaczeniu (używaniu słów). W odniesieniu do pierwszej relacji nie ma większych uwag, albowiem oczywiste jest, że język polskiego tekstu prawnego w całości zasadza się na słownictwie etnicznego języka polskiego. W odniesieniu do płaszczyzny znaczeniowej zgłaszana jest już jednak potrzeba uwzględniania pewnych wyjątków ${ }^{43}$. Zdarzać się bowiem mogą sytuacje wieloznaczności lub nieostrości ${ }^{44}$. Wieloznaczność polega na tym, że jednemu wyrażeniu może być przypisywana większa ilość treści znaczeniowych, o istniejaccym między nimi powiązaniu semantycznym (wiele zbliżonych lub podobnych znaczeń). Poza wieloznacznością (polisemicznościa) może wystapić także zjawisko homonimii, czyli wiązanie jednego kompleksu dźwiękowego i graficznego z różnymi treściami znaczeniowymi, między którymi brak jakiegokolwiek powiązania semantycznego. Sama zaś polisemia może przejawiać się w metaforze, w tym w synestezji, a także w wieloznaczności polegającej na opozycji oraz metonimii ${ }^{45}$. Wobec tego język prawny, aby minimalizować ryzyko wieloznaczności i braku precyzji, rządzi się własnymi, specyficznymi regułami w odniesieniu do konstrukcji tekstu i sposobu interpretacji. Agnieszka Chodú podkreśla, że stałymi atrybutami języka prawnego sa: 1) konstrukcja tekstu tworzona w oparciu o ustandaryzowane procedury (ZTP); 2) formalność tekstu przejawiająca się w spójności linearnej i semantycznej; 3) leksy-

39 S. Wronkowska, M. Zieliński, op. cit., s. 42.

${ }^{40}$ G. Wierczyński, Redagowanie i ogłaszanie aktów normatywnych. Komentarz, Warszawa 2010, s. 99.

41 Ibidem, s. 98; S. Wronkowska, M. Zieliński, op. cit., s. 42.

42 M. Zieliński, op. cit., s. 144.

43 Ibidem, s. 145-147.

${ }^{44}$ Z. Tobor, W poszukiwani intencji prawodawcy, Warszawa 2013, s. 24; M. Zieliński, Aspekty zasady clara non sunt interpretanda, w: S. Wronkowska, M. Zieliński, Szkice z teorii prawa i szczegółowych nauk prawnych, Poznań 1990, s. 88; T. Spyra, Granice wykładni prawa. Znaczenie językowe tekstu prawnego jako granica wykładni, Kraków 2006, s. 172-173.

45 E. Łuczyński, J. Maćkiewicz, Językoznawstwo ogólne. Zagadnienia wstępne, Gdańsk 1999, s. 37 i n.; M. Zieliński, Wyktadnia prawa..., s. 148 i n.; Z. Tobor, op. cit., s. 153-188; A. Malinowski, op. cit., s. 25-31. 
ka wspólnoodmianowa w pierwszej warstwie i swoista w drugiej (książkowa, zawodowa, urzędowa, naukowa) ${ }^{46}$. Słownictwo języka prawnego powinno być starannie dobrane i nacechowane oficjalnościa, właściwą dla leksyki książkowej, urzędowej, zawodowej oraz naukowej. Nie jest to słownictwo potoczne. Nie istnieje dowolność i swoboda w użyciu polisemicznych, homonimicznych i kontekstowych słów, embolofazji lub innych sposobów wypowiedzi.

Z uwagi na powyższe poza koniecznością - w myśl § 75 ust. 1 ZTP - wyczerpujacego określenia znamion czynu zabronionego, przy formułowaniu ich opisu należy kierować się zasadą precyzji, jasności, adekwatności, a także komunikatywności ${ }^{47}$. Adekwatność czyni zadość wymogowi najprecyzyjniejszego odniesienia się do zamyślonego przez ustawodawcę desygnatu, jakim jest typ czynu $^{48}$. Następuje to przez używanie słów, konstruowanie całych zdań oraz całego tekstu aktu prawnego, których treść znaczeniowa w granicach treści normy sankcjonowanej jest najodpowiedniejsza (najprecyzyjniejsza). Komunikatywność zaś jako doniosła społecznie kreuje obowiązek zbliżenia się do desygnatu przez posługiwanie się słowami o tożsamym lub przynajmniej najbardziej zbliżonym do nich znaczeniu z języka powszechnego. Innymi słowy, przepis ma być zrozumiały nie w jakikolwiek sposób, lecz zgodnie z intencja ustawodawcy, a przy tym ma być zrozumiały dla możliwie najszerszego grona odbiorców ${ }^{49}$. Komunikatywność w przypadku przepisu karnego zdaje się doniosła z uwagi na zaadresowanie norm sankcjonowanych do społeczeństwa powszechnego.

Niemniej racjonalny ustawodawca, starając się zachować równowagę, może jedynie zbliżyć się do zagwarantowania komunikatywności, jasności, adekwatności i precyzji w sposób asymptotyczny ${ }^{50}$. Dlatego też swoistym uzupełnieniem języka prawnego, który przecież nie może być doskonale jednoznaczny i jasny, jest ,język prawniczy”. Z tym ostatnim ściśle wiąże się proces wykładni normy prawnej z przepisu prawnego. Wykładnia stanowi nic innego jak proces myślowy, w ramach którego czytelnik przepisu dąży do jego zrozumienia, tj. dąży do ustalenia, o co chodziło ustawodawcy w ramach stanowionego przepisu. Warto podkreślić, że w polskiej myśli prawniczej prezentowane sa dwa podstawowe podejścia w odczytywaniu przepisu prawnego, tj. klaryfikacyjne (clara non sunt interpretanda, czyli jasne nie wymaga interpretacji) i derywacyjne (omnia sunt interpretanda, czyli wszystko wymaga interpretacji) ${ }^{51}$. W spółcześnie coraz częściej mówi się jednak o potrzebie integrowania tych dwóch sposobów wykładni. Ich wspólna płaszczyzną miało by być traktowanie teorii klaryfikacyjnej jako fragmentu szerszego, derywacyjnego podejścia ${ }^{52}$. Zdaniem Macieja Zielińskiego i Marka Zirka-Sadowskiego „o ile teoria klaryfikacyjna koncentruje się wprost

${ }^{46}$ A. Choduń, op. cit., s. 29.

${ }^{47}$ G. Wierczyński, op. cit., s. 97 i n.

48 S. Wronkowska, M. Zieliński, Komentarz do zasad..., s. 36.

49 Ibidem, s. 36-37.

50 Ibidem, s. 37.

51 M. Zieliński, M. Zirk-Sadowski, Klaryfikacyjność i derywacyjność w integrowaniu polskich teorii wyktadni prawa, „Ruch Prawniczy, Ekonomiczny i Socjologiczny” 73, 2011, z. 2, s. 99.

${ }^{52}$ Ibidem. 
na pozyskiwaniu jasności przepisów prawnych (norm prawnych), o tyle teoria derywacyjna problemy klaryfikacyjne poprzedza analizą zagadnień związanych $\mathrm{z}$ rozumieniem tekstów prawnych ze względu na występujace w nich rozczłonkowanie syntaktyczne i treściowe" ${ }^{53}$.

Kluczowe dla niniejszych rozważań jest jednak to, że w zakresie każdej z koncepcji istnieje potrzeba „wyeliminowania błędnego »domniemania potoczności języka prawnego« i ustalania właściwych relacji i udziału języka prawnego, prawniczego i ogólnego języka polskiego w procesie interpretacji tekstów aktów prawnych, itp." ${ }^{54}$. Interpretator tudzież - jak wskazuje się konstruktor w odniesieniu do normy prawnej, a interpretator w odniesieniu do intencji ustawodawcy ${ }^{55}$, przechodząc do fazy percepcyjnej wykładni, winien mieć na względzie, że racjonalny albo przynajmniej faktyczny ustawodawca przez użyte słowo lub całą frazę odnosi się - nie majac tutaj na uwadze definicji legalnych - wyłącznie do konkretnego zakresu znaczeniowego, czerpanego z języka powszechnego. Jak podkreśla Zygmunt Tobor, niezależnie od podejścia do wykładni tekstu prawnego, przez tekstualizm, intencjonalizm, kontekstualizm, każdy podejmujący się odczytania treści normy prawnej dąży do ustalenia intencji prawodawcy ${ }^{56}$. Różnice jedynie istnieją w proponowanych aksjologicznych uzasadnieniach przełamania znaczenia literalnego ${ }^{57}$. Nadto w odniesieniu do zagadnienia wieloznaczności Tobor podkreśla, że pojawia się ona, gdy następuje sięgnięcie właśnie do ustaleń semantycznych lub syntaktycznych ${ }^{58}$. Problem wieloznaczności rozstrzyga się najczęściej przez wybór jednego ze znaczeń spośród proponowanych przez słownik języka polskiego.

Zygmunt Tobor wskazuje jednak dalej, że sam język nie jest wystarczającym źródłem argumentów, na podstwie których można by było dokonać należytego uzasadnienia wyboru jednego znaczenia spośród proponowanych na gruncie języka ogólnego. Jak podkreśla - konsekwencją jest odwołanie się do tzw. kategorii celu ${ }^{59}$. Agnieszka Chodun zaznacza, że „zarówno redaktor tekstu prawnego, jak i jego interpretator, nie moga polegać jedynie na swojej intuicji językowej bez odwoływania się do słowników języka polskiego, w których zawarto ustalenia poczynione przez językoznawców”60.

Z uwagi na powyższe interpretator powinien być wyczulony na to, iż ustawodawca dokonał wyboru tylko jednego znaczenia spośród tych, które język ogólny mu proponuje. Winien także brać pod uwagę ewentualne odstępstwa (modyfikacje) od wybranej treści znaczeniowej. Pewne względy mogą bowiem przemawiać za odstępstwem od podstawowego znaczenia z języka powszechnego. Wolno odstapić od takiego znaczenia, gdy pozostaje ono „w oczywistym

53 Ibidem.

${ }^{54}$ M. Zieliński et al., Zintegrowanie polskich koncepcji wykładni prawa, „Ruch Prawniczy, Ekonomiczny i Socjologiczny” 71, 2009, z. 4, s. 38.

55 Z. Tobor, op. cit., s. 20.

56 Ibidem, s. 27.

57 Ibidem, s. 149-150.

58 Ibidem, s. 180-181.

59 Ibidem, s. 186.

${ }^{60}$ A. Choduń, op. cit., s. 30. 
konflikcie lub sprzeczności ze znaczeniem innych norm systemu, gdy prowadzi do absurdalnych z punktu widzenia społecznego lub ekonomicznego konsekwencji, gdy prowadzi do rażąco niesprawiedliwych rozstrzygnięć lub pozostaje $\mathrm{w}$ oczywistej sprzeczności z powszechnie akceptowanymi normami moralnymi” ${ }^{61}$. Chodzi wówczas o znaczenie wyprowadzane przez wykładnię systemową i wykładnię funkcjonalną. Jeżeli znaczenie takie jest wystarczająco ugruntowane w linii doktrynalno-orzeczniczej, wchodzi ono wówczas do zakresu języka prawniczego ${ }^{62}$.

Jednocześnie w prawoznawstwie spotkać można pogląd, iż błędem jest traktowanie przepisów tak, by wprost były zrozumiałe dla przeciętnych adresatów, w tym by w pierwszej kolejności można było je odczytywać na poziomie wykładni językowej, a nawet i rozumienia prima facie. Nie wydaje się jednak, aby przytoczonemu poglądowi można byłoby przypisać charakter ogólnej i bezwarunkowej zasady. Wymaga on wyważenia z uwzględnieniem specyfiki regulowanej dziedziny życia społeczno-gospodarczego, a tym samym z uwzględnieniem adresata normy. Warto podkreślić wątpliwości podnoszone przez Z. Tobora, że z jednej strony clara non sunt interpretan$d a$ może być utożsamiana z podstawowa ochrona zaufania obywateli wobec prawa i organów je stanowiących oraz stosujących, trudno bowiem od przeciętnego obywatela wymagać przeprowadzania skomplikowanych procedur interpretacyjnych, a z drugiej strony mocno przesadzone byłoby traktowanie omnia sunt interpretanda jako prowadzącej do naruszenia konstytucyjnej zasady demokratycznego państwa prawa, czy też zwiększania ograniczeń $\mathrm{w}$ dostępie do prawa ${ }^{63}$.

Jakkolwiek, mając na względzie specyfikę prawa karnego, warto przytoczyć pogląd wyrażony przez A. Zolla, gdyż jego zdaniem nie jest przekonujace, jakoby na gruncie wykładni przepisu karnego „nie jest istotna możliwość dostępu do tekstu prawnego osób spoza środowiska prawniczego. Z punktu widzenia zasad konstytucyjnych można wskazać wiele argumentów przemawiających za potrzeba formowania tekstu prawnego w sposób zrozumiały dla adresatów normy i to nie pośrednio, przy pomocy specjalistów, lecz bezpośrednio" ${ }^{64}$. W orzecznictwie podkreśla się, że istnieje w tym zakresie „nakaz tworzenia przepisów klarownych i zrozumiałych dla ich adresatów, którzy od racjonalnego ustawodawcy oczekiwać mogą stanowienia norm prawnych nie budzących wątpliwości, co do treści nakładanych obowiązków i przyznawanych praw”"65. W ten sposób, w myśl związania z precyzją przepisu prawnego, treść normy prawnej (obowiązków i praw) - precyzja przepisu - winna być oczywista i pozwalająca na jego wyegzekwowanie ${ }^{66}$.

${ }^{61}$ Wyrok SN z 8 maja 1998 r., I CKN 664/97, Lex nr 34214.

${ }^{62}$ A. Michalska, S. Wronkowska, op. cit., s. 67; M. Zieliński, Wyktadnia prawa..., s. 335.

${ }^{63}$ Z. Tobor, op. cit., s. 25-26.

${ }^{64}$ A. Zoll, Recenzja rozprawy habilitacyjnej oraz dorobku naukowego dr Piotra Wiatrowskiego, Kraków 2013, s. 3.

${ }^{65}$ Wyrok TK z 21 maja 2001 r., K 24/00, Lex nr 46863.

${ }^{66}$ Wyrok TK z 29 października 2003 r., K 53/02, Lex nr 81788. 


\section{KONKLUZJE}

W toku formułowania opisu ujmowanych w „umyśle ustawodawcy” desygnatów, czyli typów kryminalizowanych zachowań, bądź też poszczególnych elementów kompleksu danego typu zachowania, a także cech podmiotu (sprawcy) i okoliczności modalnych sytuacji, miejsca i czasu - ustawodawca winien mieć na uwadze konieczność przyjęcia takiego wyrażenia (lub zespołu wyrażeń), które na gruncie języka powszechnego będzie (lub będa) odpowiadać wprost temu desygnatowi (zachowaniu, sprawcy itp.). Jeżeli jednak jest to niemożliwe, to powinien dobierać słowa, które znajdują się znaczeniowo najbliżej tego desygnatu, z możliwością optymalnej modyfikacji ich znaczenia (przybliżenia do desygnatu przez odrzucenie, dodanie lub zamianę elementów konotacyjnych treści znaczeniowej danego słowa lub słów) ${ }^{67}$. Modyfikacja ta dopuszczalna jest o tyle, o ile nie spowoduje wyprowadzenia danego słowa spoza granic powszechnie nakreślanej mu kategorii semantycznej68. Tylko w wyjątkowych sytuacjach wolno odstapić od literalnego znaczenia ${ }^{69}$. Modyfikacja ta dopuszczalna jest wyłącznie $\mathrm{w}$ ograniczonym do niezbędnego minimum zakresie, na potrzeby realizacji aksjologii i teleologii normy prawnokarnej ${ }^{70}$, a jednocześnie powinna zadość czynić regułom właściwym dla specyfiki danej gałęzi prawa, w tym przypadku - prawa karnego ${ }^{71}$. Ewentualne modyfikacje nie mogą odbiegać od znaczenia podstawowego i powszechnego tak, aby nie nastapiło jego wyparcie (wypaczenie) przez znaczenie doczytywane (interpretowane) w doktrynie i orzecznictwie. Posługiwanie się znaczeniem spotykanym co do zasady w orzecznictwie, czy też w doktrynie, a nie w języku ogólnym i powszechnym, może prowadzić do braku bezpośredniego i powszechnego zrozumienia przepisu karnego. Skutkiem tego może być wieloznaczność przepisu, w tym niedookreśloność znamion (brak precyzji, zawiłość lub nadmierna szerokość znamion). Niedookreśloność zakresu kryminalizacji powodować będzie naruszenie nullum crimen sine lege certa. Skutkiem takiego stanu będzie także osłabienie zasady ignorantia iuris nocet, albowiem zachodzić będzie mogła niemożliwość zrozumienia, co jest zasadniczo przestępstwem ${ }^{72}$. Intencja ustawodawcy, w ramach której ten dążyłby do kryminalizacji określonego rodzaju zachowań społecznie niebezpiecznych, może okazać się niemożliwą do zrealizowania i blokowaną chociażby na gruncie okoliczności ekskulpacyjnej w postaci nieświadomości co do bezprawności czynu. Trzeba bowiem pamiętać, że ustawa karna jest zaadresowana do ogółu obywateli i odbiór normy karnej,

67 E. Łuczyński, J. Maćkiewicz, op. cit., s. 35 i 36.

68 Wyrok SN z 11 kwietnia 2008 r., II CSK 650/07, Lex nr 391825; uchwała SN z 14 października 2004 r., III CZP 37/04, Lex nr 125609; wyrok TK z 28 czerwca 2000 r., K 25/99, Lex nr 41212; wyrok SN z 8 stycznia 1993 r., III ARN 84/92, Lex nr 3913; wyrok SN z 8 maja 1998 r., I CKN 664/97, Lex nr 34214.

69 Uchwała SN z 14 października 2004 r., III CZP 37/04, Lex nr 125609.

70 E. Hryniewicz, Przestępstwo abstrakcyjnego i konkretnego zagrożenia dóbr prawnych, Warszawa 2012, s. 242.

71 A. Marek, Prawo karne, wyd. 9, Warszawa 2009, s. 67.

72 K. Mamak, op. cit., s. 67. 
a ściślej ujmując - opisu zachowania, jakie jest karalne, winien już następować w bezpośredniej interakcji między tą normą a jej adresatem bez ogniw pośrednich. Dlatego też ustawodawca powinien używać wyrażeń języka polskiego w ich zwykłym i powszechnym znaczeniu, a jak podkreśla Andrzej Marek - ustawodawca: „niekiedy tylko wprowadza odmienne znaczenie używanych wyrazów (język prawny), gdy jest to niezbędne dla właściwego i operatywnego stosowania prawa. Jednak i tutaj musi się liczyć z powszechną praktyką językowa, aby nie wprowadzić zamętu pojęciowego"73.

dr Mateusz Tomczyk

Uniwersytet im. Adama Mickiewicza w Poznaniu

\section{THE PRINCIPLE NULLUM CRIMEN SINE LEGE CERTA AND ITS LIMITATIONS ON THE GROUNDS OF AN ETHNIC LANGUAGE}

\section{Sum mary}

This paper is an attempt to answer the question if it is possible to achieve full unambiguity and precision of an abstract and general description of features of a prohibited act within the substantive criminal law while maintaining communicativeness and conciseness of a legal text so that it is comprehensible for all the addressees of a criminal norm. In other words, the author seeks to resolve the issue of whether it is possible to implement the nullum crimen sine lege certa principle, which requires full characterisation of the prohibited act, to an extent that is even 'idealised.' In this respect, the author seeks to highlight the thesis that norms of criminal law describing punishable acts are addressed to the general society and as such should be read directly and understood without the need to apply complicated rules of interpretation of a criminal norm from a criminal provision at each time, which, according to the author, constitutes an element of the nullum crimen sine lege principle referred to in Article 42(1) of the Polish Constitution. However, it turns out that achieving full unambiguity and precision, without going into too much detail in a legal provision, and at the same time maintaining communicativeness and conciseness of a legal text is not possible. The reason is that criminal provisions containing a description of features of the type of a prohibited act are the result of a compromise between unambiguity, precision, communicativeness and imperfections of the ethnic language in which they were formulated. The wording of a criminal provision is asymptotic, but the legislator should be guided by the fact that it should, as far as possible, be comprehensible to every addressee, especially the one without adequate legal training.

${ }^{73}$ A. Marek, op. cit., s. 67. 